\title{
Predictive Value of Systemic Immune Inflammation Index for Postoperative Atrial Fibrillation in Patients Undergoing Isolated Coronary Artery Bypass Grafting
}

\section{İzole Koroner Arter Bypass Greft Uygulanan Hastalarda Postoperatif Atriyal Fibrilasyon için Sistemik İmmün Enflamasyon İndeksinin Öngörücü Değeri}

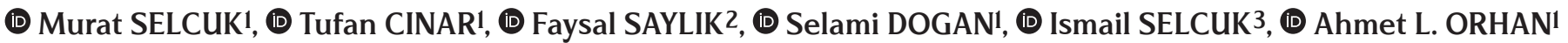

'University of Health Sciences Turkey, Istanbul Sultan 2. Abdulhamid Han Training and Research Hospital, Clinic of Cardiology, Istanbul, Turkey 2University of Health Sciences Turkey, Van Training and Research Hospital, Turkey, Clinic of Cardiology, Van, Turkey

${ }^{3}$ University of Health Sciences Turkey, Istanbul Sultan 2. Sultan Abdulhamid Training and Research Hospital, Clinic of Cardiovascular Surgery, Istanbul, Turkey

\begin{abstract}
Objective: Inflammation plays an important role in the initiation of postoperative atrial fibrillation (PoAF) in individuals undergoing cardiac surgery. Thus, this study aimed to investigate the predictive value of the systemic immune inflammation index (SII) to develop PoAF in such patients.

Methods: In total, 391 consecutive patients undergoing an isolated coronary artery bypass grafting (CABG) were retrospectively analyzed. PoAF was defined according to the current guideline. The SIl is determined using the following equation: neutrophil $(\mathrm{N}) \times$ platelet $(\mathrm{P}) \div$ lymphocyte $(\mathrm{L})$

Results: The incidence of PoAF in the present study was 24\% ( $\mathrm{n}=97$ cases). Multivariate logistic regression analysis revealed that the SII was an independent predictor of PoAF (Odds ratio: 1.002 95\% confidence interval: (1.001-1.002), p<0.01). The optimal value of the SII in detecting PoAF was established by a receiver operating characteristic curve assessment, and it was $>807.8$ with $60.8 \%$ sensitivity and $80.9 \%$ specificity [area under the curve (AUC): 0.7107]. The AUC value of SII in detecting PoAF was much greater than the AUC values of both the neutrophil to lymphocyte ratio (NLR) and the platelet to lymphocyte ratio (PLR) (AUC: 0.6740 and AUC: 0.6426 , respectively).

Conclusions: This study revealed that SII was an independent predictor of PoAF in patients who were operated on for isolated CABG. Additionally, SII had a better discriminative ability for PoAF compared to either NLR or PLR among these cases.

Keywords: SII, postoperative atrial fibrillation, coronary artery bypass grafting, predictive
\end{abstract}

Received: 20 September 2021

Accepted: 25 November 2021

Online First: 17 December 2021

Corresponding Author

M. Selcuk

University of Health Sciences Turkey, Istanbul Sultan 2. Abdulhamid Han Training and Research Hospital, Clinic of Cardiology, Istanbul, Turkey

murat-slck@hotmail.com ORCID: 0000-0002-6386-0142

\section{öz}

Amaç: Enflamasyon, kalp cerrahisi olan hastalarda postoperatif atriyal fibrilasyon (PoAF) başlangııında önemli bir rol oynadığından, bu çalışma bu tür hastalarda PoAF gelişimi için sistemik immün enflamasyon indeksinin (SII) öngörücü değerini araştırmayı amaçladı.

Yöntemler: Toplamda, izole bir koroner arter baypas greft (KABG) uygulanan 391 ardışık hasta geriye dönük olarak analiz edildi. PoAF mevcut kılavuza göre tanımlanmıştır. SII nötrofil (N) x trombosit $(\mathrm{T}) \div$ lenfosit (L) formülü kullanılarak belirlendi.

Bulgular: Bu çalışmada PoAF insidansı \%24'tür ( $\mathrm{n}=97$ olgu). Çok değişkenli lojistik regresyon analizi, SIl'nin PoAF'nin bağımsız bir öngörücüsü olduğunu ortaya çıkarmıştır [olasılık oranı: \%95 güven aralığı: 1,002 (1,0011,002), p<0,01]. PoAF tespitinde SII'nin optimal değeri, alıcı işletim karakteristik eğri değerlendirmesi ile 
belirlendi ve SII'nin ideal değeri \%60,8 duyarlılık ve \%80,9 özgüllük [eğri altı alanı (EAA): 0,7107] ile 807,8'den büyük olarak belirlendi. PoAF'nin tespitinde SIl'nin EAA, nötrofil/lenfosit oranının (NLO) veya trombosit/lenfosit oranının (TLO) (sırasıyla EAA: 0,6740 ve EAA: 0,6426) EAA'sından daha yüksekti.

Sonuçlar: Bu araştırmada, izole KABG nedeniyle ameliyat edilen hastalarda SII'nin PoAF'nin bağımsız bir öngörücüsü olduğunu gösterdik. Ek olarak SII, bu olgular arasında NLO veya TLO'ya kıyasla PoAF için daha iyi ayırt etme yeteneğine sahipti.

Anahtar kelimeler: SII, postoperatif atriyal fibrilasyon, koroner arter baypas greft, öngörücü

\section{INTRODUCTION}

Postoperative atrial fibrillation (PoAF) is the most commonly observed supraventricular arrhythmia following cardiovascular surgery, with an estimated incidence of $20 \%-40 \%$. It typically occurs on postoperative 2-4 days and often spontaneously terminates without any interventions ${ }^{2}$. Prior studies showed that the development of PoAF after cardiac surgery was linked with longer hospitalization, higher risk of thromboembolic events, and a slightly increased risk of death during the index hospitalization ${ }^{3}$. Furthermore, the occurrence of PoAF has been demonstrated to be significantly related to an increased risk of stroke in the long-term followup $^{4}$. The exact mechanisms of PoAF following cardiac surgery are complex and incompletely defined; however, inflammation, sympathetic activation, and cardiac ischemia are shown to induce and maintain $\mathrm{PoAF}^{5}$. Particularly, systemic inflammation had previously been shown to predict the onset and recurrence of PoAF in patients who had undergone cardiac surgery, including coronary artery bypass grafting $(\mathrm{CABG})^{6-8}$.

The systemic immune inflammation index (SII), which is developed to assess patients' inflammatory state, is determined using the following equation: neutrophil $(\mathrm{N})$ × platelet $(\mathrm{P}) \div$ lymphocyte $(\mathrm{L})^{9}$. Previously, cancer cases with higher SII were shown to have poor outcomes and increased mortality ${ }^{9.10}$. Additionally, the predictive value of this index has been examined in predicting deaths in cases with acute and chronic coronary syndromes $(C C S)^{11,12}$. Nevertheless, the current literature reported insufficient data on the usefulness of SII in predicting the PoAF occurrence in patients after cardiac surgery, especially those undergoing an isolated CABG. Systemic inflammation plays an important role in the initiation of PoAF in patients following cardiac surgery, thus, this study mainly aimed to explore the predictive accuracy of this index for PoAF occurrence in such patients.

\section{MATERIALS and METHODS}

\section{Study Population}

Firstly, consecutive cases with symptomatic coronary artery disease that underwent an isolated CABG at our facility between January 2018 and January 2021 were screened. Then, those who had acute and chronic infections, chronic inflammatory or autoimmune dysfunction, liver problems, malignancy, and significant valvular heart diseases as well as those previously diagnosed with AF were excluded. Therefore, 391 patients undergoing an isolated CABG were analyzed in this study. All patients were operated on with isolated on-pumpCABG. Clinical and laboratory data of all patients were obtained from the hospital electronic database. Additionally, data regarding the intraoperative procedures were collected, including the aortic cross-clamp time, the number of distal anastomoses, left internal mammary artery (LIMA) graft use, cardiopulmonary bypass (CPB) time, drainage amount, intubation time, the use of inotropic support, and the use of blood products. PoAF was defined according to the European Society of Cardiology AF guidelines, with a duration of at least $30 \mathrm{~s}$. Per hospital protocol, patients with hemodynamically stable PoAF were firstly managed with medical cardioversion. Those who did not convert to sinus rhythm with medical cardioversion underwent electrical cardioversion. In the case of hemodynamic instability, direct electrical cardioversion was performed. Patients that were previously diagnosed with AF were excluded, thus no patients used any antiarrhythmic medication. Per hospital protocol, AF prophylaxis was left to the attending physician's decision. The anatomical synergy between percutaneous coronary intervention with Taxus and cardiac surgery (SYNTAX) score was applied to assess the complexity of coronary artery disease using the web online calculator (http://syntaxscore.org). The University of Health Sciences Turkey, Hamidiye Scientific Research Ethics Committee has reviewed and approved our study protocol (decision number: 13/7, date: 09.04.2021).

\section{SII and Transthoracic Echocardiography Examination}

For each case, venous samples were collected from the antecubital vein before cardiac surgery. An auto-analyzer was used to assess all blood cell counts, including neutrophils, lymphocytes, and platelets. The SII was computed as $\mathrm{P} \times \mathrm{N} \div \mathrm{L}$ ratio. 
Transthoracic echocardiography was performed for each case included in the study. The left ventricle ejection fraction (LVEF) was determined based on the modified Simpson method. Additionally, the left anteroposterior atrial diameter (LAPd) was determined from the parasternal long-axis. The LA volume index (LAVI) was computed by dividing the volume of the LA by the surface body area.

\section{Statistical Analysis}

All statistical calculations were performed using SAS University Edition (Copyright ${ }^{\circ}$ 2015, SAS Institute Inc., Cary, NC, USA). The Kolmogorov-Smirnov test was used to assess the normality of data. Quantitative variables with a normal distribution were reported as mean (standard deviation), and those without a normal distribution were expressed as median (interquartile range). Categorical variables were presented as numbers and percentages. The independent Student's t-test and Mann-Whitney $\mathrm{U}$ tests were used for inter-group comparisons of continuous variables. The chi-square test or Fisher's Exact test was used to compare categorical variables, as appropriate. Univariate logistic regression analysis was used to determine the predictors of PoAF. A multivariable logistic regression analysis was performed with variables that exhibit statistical significance in univariate logistic regression $(\mathrm{p}<0.05)$. To avoid multicollinearity, neutrophil to lymphocyte ratio (NLR), platelet to lymphocyte ratio (PLR), neutrophil, lymphocyte, and platelet were excluded from the multivariable logistic regression model. Receiver operating characteristic (ROC) curve analysis was performed to obtain the best SII cutoff value for predicting PoAF. The Bayesian information criterion (BIC), 2 Log likelihood (-2LL), Akaike information criterion (AIC), and area under the curve (AUC) were used to assess the comparisons of the abilities of variables to predict PoAF. Lower levels of AIC, BIC, and -2LL indicate a better model fit, and a high AUC value indicates effective discrimination ability for the diagnostic prediction. A 2-sided p-value of $>0.05$ was considered significant, and the confidence interval was set at $95 \%$.

\section{RESULTS}

The research population was grouped into two categories as patients who developed PoAF and those who did not. The incidence of PoAF in the present study was $24 \%$ ( $n=97$ cases). Baseline features and previous medications of all cases are displayed in Table 1. Both groups were similar in terms of comorbidities and previous medications. Additionally, LVEF, LAPd, and LAVI were not different in both groups.
Table 2 presents the data of laboratory results and intraoperative data of each case that is included in the study. Patients who developed PoAF had higher neutrophil, monocyte count, C-reactive protein (CRP), NLR, PLR, and SII but lower lymphocyte counts. Other laboratory data were similar between the groups. Both groups had similar intraoperative data, including aortic cross-clamp time, number of distal anastomoses, LIMA graft use, CPB time, drainage amount, intubation time, the use of inotropic support, and the use of blood products. As expected, patients with PoAF had a longer stay in the

\begin{tabular}{|c|c|c|c|}
\hline & $\begin{array}{l}\text { PoAF (+) } \\
(\mathbf{n}=97)\end{array}$ & $\begin{array}{l}\text { PoAF (-) } \\
(n=294)\end{array}$ & p-value \\
\hline Age, years & $58.8 \pm 11.2$ & $57.1 \pm 12.9$ & 0.261 \\
\hline Male, n (\%) & $70(72.2)$ & $229(77.9)$ & 0.249 \\
\hline $\begin{array}{l}\text { Hypertension, } \\
\mathrm{n}(\%)\end{array}$ & $34(35)$ & $98(33.3)$ & 0.756 \\
\hline $\begin{array}{l}\text { Diabetes mellitus, } \\
\mathrm{n}(\%)\end{array}$ & $31(31.9)$ & $81(27.6)$ & 0.405 \\
\hline $\begin{array}{l}\text { Hyperlipidemia, } \\
\text { n (\%) }\end{array}$ & $34(35)$ & $92(31.3)$ & 0.492 \\
\hline Smoking, n (\%) & $43(44.3)$ & $118(40.1)$ & 0.467 \\
\hline $\begin{array}{l}\text { Body mass index, } \\
\mathrm{kg} / \mathrm{m}^{2}\end{array}$ & $\begin{array}{l}23.6 \\
(20.9-26.8)\end{array}$ & $23.4(21.2-26.1)$ & 0.511 \\
\hline $\begin{array}{l}\text { Cerebrovascular } \\
\text { disease, n (\%) }\end{array}$ & $8(8.3)$ & $21(7.1)$ & 0.719 \\
\hline $\begin{array}{l}\text { Peripheral artery } \\
\text { disease, } n(\%)\end{array}$ & $13(13.4)$ & $26(8.8)$ & 0.194 \\
\hline COPD, n (\%) & $16(16.5)$ & $32(10.9)$ & 0.144 \\
\hline LVEF, \% & $50(45-55)$ & $50(45-60)$ & 0.109 \\
\hline Heart rate, bpm & $69(62-77)$ & 70 (65-76) & 0.103 \\
\hline $\begin{array}{l}\text { Left atrium } \\
\text { diameter, mm }\end{array}$ & $38(35-41)$ & $39(36-41)$ & 0.191 \\
\hline $\mathrm{LAVI}, \mathrm{mL} / \mathrm{m}^{2}$ & $27.3(3.2)$ & $26.7(2.8)$ & 0.08 \\
\hline \multicolumn{4}{|c|}{ Previous medications } \\
\hline $\begin{array}{l}\text { Acetylsalicylic } \\
\text { acid, n (\%) }\end{array}$ & $45(46.4)$ & $149(50.7)$ & 0.464 \\
\hline Beta-blocker, n (\%) & $41(42.3)$ & $131(44.6)$ & 0.694 \\
\hline $\begin{array}{l}\text { Calcium channel } \\
\text { blocker, n (\%) }\end{array}$ & $12(12.4)$ & $39(13.3)$ & 0.821 \\
\hline $\begin{array}{l}\text { ACE inhibitor, } n \\
(\%)\end{array}$ & $26(26.8)$ & $84(28.6)$ & 0.737 \\
\hline Statin, n (\%) & $24(24.7)$ & $61(20.8)$ & 0.408 \\
\hline
\end{tabular}


Table 2. Laboratory and intraoperative data of all cases.

\begin{tabular}{|c|c|c|c|}
\hline & $\begin{array}{l}\text { PoAF }(+) \\
(\mathbf{n}=97)\end{array}$ & $\begin{array}{l}\text { PoAF (-) } \\
(n=294)\end{array}$ & p-value \\
\hline \multicolumn{4}{|l|}{ Laboratory data } \\
\hline Hemoglobin, g/L & $14.3(1.9)$ & $14.4(1.7)$ & 0.529 \\
\hline Platelet count, $\mu \times 10^{3} / \mu \mathrm{L}$ & $250.8(62.4)$ & $239.5(62.6)$ & 0.124 \\
\hline Neutrophil count, $\mu \times 10^{3} / \mu \mathrm{L}$ & $5.7(4.4-7.6)$ & $4.9(3.6-6.5)$ & $<0.001$ \\
\hline Lymphocyte count, $\mu \times 10^{3} / \mu \mathrm{L}$ & $1.9(1.4-2.3)$ & $2.2(1.6-2.9)$ & $<0.001$ \\
\hline Monocyte count, $\mu x 10^{3} / \mu \mathrm{L}$ & $0.6(0.4-0.8)$ & $0.5(0.4-0.7)$ & $<0.001$ \\
\hline Creatinine, mg/dL & $0.9(0.7-1)$ & $0.8(0.7-1)$ & 0.089 \\
\hline Potassium, mEq/L & $4.1(3.9-4.6)$ & $4.1(3.8-4.5)$ & 0.176 \\
\hline Magnesium, mEq/L & $2.1(0.4)$ & $2.2(0.5)$ & 0.358 \\
\hline CRP, mg/dL & $2.6(2.3-3.5)$ & $2.3(1.4-3.6)$ & $<0.001$ \\
\hline LDL, mg/dL & $114(95-142)$ & $113(95-139)$ & 0.730 \\
\hline $\mathrm{HDL}, \mathrm{mg} / \mathrm{dL}$ & $32(27-41)$ & $(26-36)$ & 0.087 \\
\hline Triglyceride, mg/dL & $134(95-184)$ & $153(108-192)$ & 0.128 \\
\hline NLR & $3.8(2-4.7)$ & $2.1(1.6-2.8)$ & $<0.001$ \\
\hline PLR & $126.7(100-206.9)$ & $105.6(80.4-147.7)$ & $<0.001$ \\
\hline SII & $908(455-1435)$ & $486(353-716)$ & $<0.001$ \\
\hline \multicolumn{4}{|l|}{ Intraoperative findings } \\
\hline Aortic cross-clamp time, min & $60(55-64)$ & $59(49-64)$ & 0.125 \\
\hline Number of distal anastomoses, n (IQR) & $3(2-3)$ & $3(2-3)$ & 0.663 \\
\hline LIMA graft use, $n(\%)$ & $93(95.9)$ & $287(97.6)$ & 0.477 \\
\hline CPB time, min & $80(80-100)$ & $80(65-100)$ & 0.218 \\
\hline Amount of drainage, $\mathrm{mL}$ & $700(400-1000)$ & $700(440-930)$ & 0.751 \\
\hline Intubation time, $\mathrm{h}$ & $7(5-10)$ & $7(5-10)$ & 0.796 \\
\hline Stay in the ICU, h & $40(28-52)$ & $37(25-52)$ & 0.025 \\
\hline Use of inotropic support, $\mathrm{n}(\%)$ & $12(12.4)$ & $23(7.8)$ & 0.174 \\
\hline Use of blood products, $\mathrm{n}(\%)$ & $27(27.8)$ & $58(19.7)$ & 0.093 \\
\hline SYNTAX score & $23.3(6.5)$ & $22.5(5.1)$ & 0.246 \\
\hline
\end{tabular}

intensive care unit (ICU). Additionally, the SYNTAX score was similar between the groups.

Both univariable and multivariable logistic regression analyses were applied to identify the determinants of PoAF. LVEF, neutrophil count, lymphocyte count, monocyte count, SII, CRP, and ICU stay were determinants of PoAF in univariable analysis. Multivariate logistic regression analysis revealed that monocyte count, SII (odds ratio: 95\% confidence interval: 1.002 (1.001-1.002), $\mathrm{p}<0.01$ ), CRP, and ICU stay were independent predictors for PoAF (Table 3). As shown in Table 4, SII had lower AIC, BIC, and -2LL, and higher AUC values.
The ROC curve assessment revealed that the optimal value of the SIl level in detecting PoAF was $>807.8$ with $60.8 \%$ sensitivity and $80.9 \%$ specificity (AUC: 0.7107 ) (Figure 1). Of note, the AUC value of SIl in detecting PoAF was much higher than the AUC values of the NLR and PLR (AUC: 0.6740 vs. AUC: 0.6426 , respectively). According to a boxplot assessment, individuals with PoAF had considerably greater SII than those without PoAF (Figure 2).

\section{DISCUSSION}

This study revealed that SII was a significant and independent predictor of PoAF in patients who were 
Table 3. Univariable and multivariable logistic regression analysis for PoAF predictors.

\begin{tabular}{|c|c|c|c|c|}
\hline & \multicolumn{2}{|c|}{ Univariable } & \multicolumn{2}{|c|}{ Multivariable } \\
\hline & OR $(95 \% \mathrm{CI})$ & p-value & OR $(95 \% \mathrm{CI})$ & p-value \\
\hline LAVI & $1.074(0.992-1.163)$ & 0.078 & - & - \\
\hline LVEF & $0.970(0.944-0.997)$ & 0.031 & - & - \\
\hline Neutrophil & $1.229(1.096-1.381)$ & $<0.001$ & - & - \\
\hline Lymphocyte & $0.502(0.362-0.678)$ & $<0.001$ & - & - \\
\hline Monocyte & $1.024(1.012-1.037)$ & $<0.001$ & $1.017(1.004-1.031)$ & 0.011 \\
\hline NLR & $1.381(1.221-1.573)$ & $<0.001$ & - & - \\
\hline PLR & $1.008(1.004-1.011)$ & $<0.001$ & - & - \\
\hline SII & $1002(1.001-1.002)$ & $<0.001$ & $1.002(1.001-1.002)$ & $<0.001$ \\
\hline CRP & $1.360(1.112-1.668)$ & 0.003 & 1.299 (1.035-1.635) & 0.025 \\
\hline SYNTAX score & $1.029(0.986-1.073)$ & 0.187 & - & - \\
\hline Stay in the ICU & $1.016(1.000-1.032)$ & 0.047 & 1.018 (1.000-1.037) & 0.047 \\
\hline
\end{tabular}

\begin{tabular}{|c|c|c|c|c|}
\hline & AIC & BIC & AUC & $-2 L L$ \\
\hline NLR & 437.8 & 445.7 & 0.674 & 433.8 \\
\hline PLR & 455.1 & 463.1 & 0.643 & 451.1 \\
\hline SII & 416.6 & 424.6 & 0.711 & 412.6 \\
\hline
\end{tabular}

PoAF: Postoperative atrial fibrillation, NLR: Neutrophil to lymphocyte ratio, PLR: Platelet to lymphocyte ratio, SII: Systemic immune inflammation index, AIC: Akaike information criterion, BIC: Bayesian information criterion, AUC: Area under the curve, -2LL: 2 Log likelihood

operated on for isolated CABG. Additionally, elevated preoperative SII had a better effective discriminative ability for PoAF compared to either NLR or PLR among these cases.

PoAF is the most commonly observed arrhythmia complication that develops after cardiovascular surgery. The incidence of such complication is slightly higher after valve-replacement surgery; however, it occurs in approximately $30 \%$ of cases undergoing CABG. Allying with the current literature, the incidence of PoAF in our study was $24 \%{ }^{13}$. Current data indicates that PoAF does slightly prolong the hospital stay duration; however, it is less likely to have an impact on the survival of cases compared with chronic $\mathrm{AF}^{14}$. Similarly, in the present investigation, patients who developed PoAF were observed to have longer ICU stays than those who did not. In the current knowledge, growing evidence shows that inflammation plays a crucial role both in the onset and maintenance

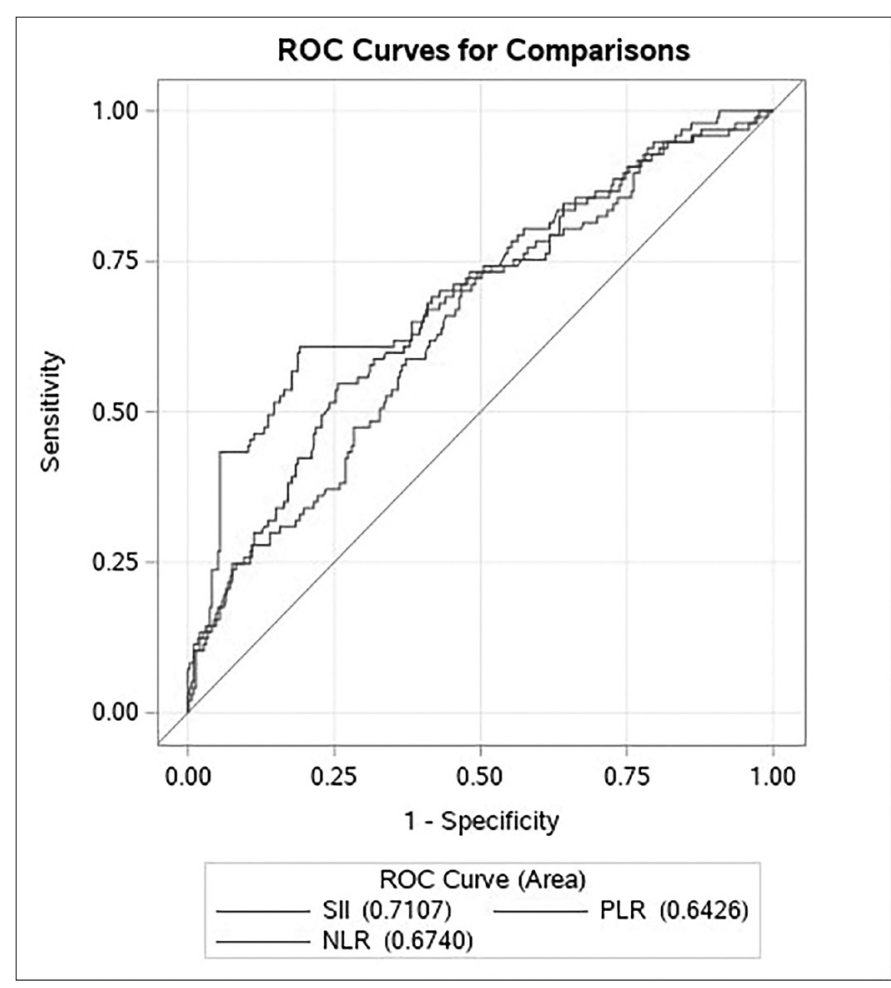

Figure 1. Receiver operating characteristics curve comparisons of systemic immune inflammation index, neutrophil to lymphocyte ratio, and platelet to lymphocyte ratio.

SII: Systemic immune inflammation index, NLR: Neutrophil to lymphocyte ratio, PLR: Platelet to lymphocyte ratio, ROC: Receiver operating characteristic 


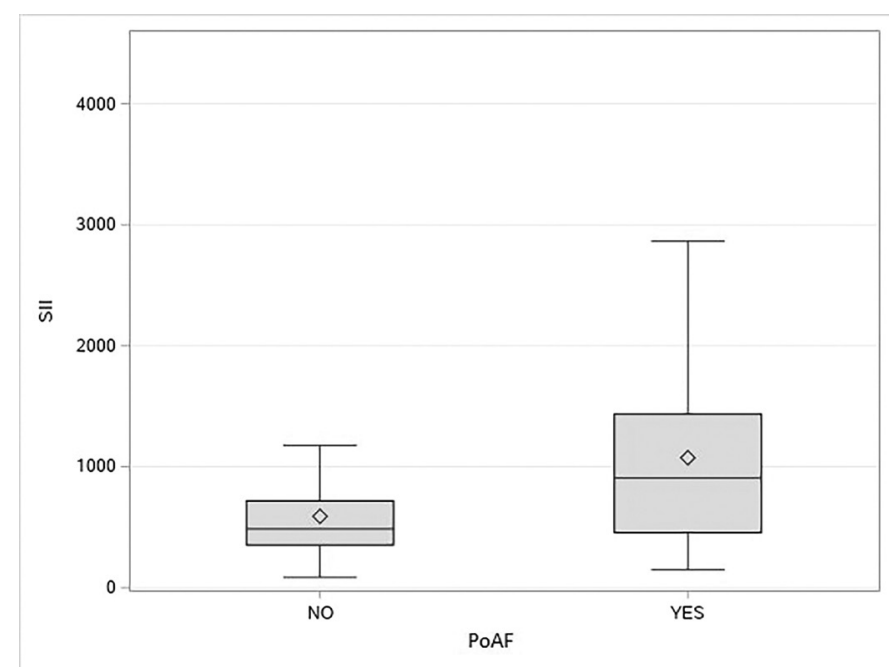

Figure 2. A box-plot analysis of systemic immune inflammation index in patients with and without postoperative atrial fibrillation.

PoAF: Postoperative atrial fibrillation, SII: Systemic immune inflammation index

of PoAF after cardiovascular surgery ${ }^{6,7}$. Previously, several well-known markers of inflammation, such as CRP and interleukin-6, were linked with an increased risk of PoAF following cardiac surgery ${ }^{15,16}$. Similar to these previous studies, an independent relationship was observed between the CRP and PoAF in our study. Hence, it can be concluded that inflammatory markers can be used to determine the risk of PoAF in patients undergoing CABG. A previous study demonstrated that a high SYNTAX score was linked with more frequent PoAF in patients undergoing isolated on-pump CABG ${ }^{17}$. However, the SYNTAX score was not an independent predictor of PoAF in our study since our study population included only patients undergoing isolated on-pump CABG, in whom the SYNTAX score was high. Our study revealed that both LA diameters and LAVI were comparable between the groups. Patients with significant valvular heart disease and those previously diagnosed with AF were eliminated, thus these findings might be expected.

The SII is an innovative inflammatory biomarker that combines neutrophil, lymphocyte, and platelet counts to reflect the overall inflammatory status of the body. The predictive value of this index has been examined for poor outcomes in individuals who suffer from a variety of cancers ${ }^{10.18}$. Additionally, a prior investigation by Seo et al..$^{19}$ revealed the predictive accuracy of SII for mortality in chronic heart failure cases. Moreover, some previous studies compared the prognostic significance of this index to its components, including NLR or PLR.
For example, in a recent investigation by Erdoğan et al. ${ }^{20}$, SII levels have been shown to hemodynamically predict severe coronary obstruction better than either NLR or PLR in patients with the CCS. Another study by Yang et al. ${ }^{21}$ revealed that SII predicted major cardiovascular events better than traditional risk factors in CCS cases after the intervention. However, the current knowledge reported no data about the use of SII in predicting PoAF in patients who underwent an isolated CABG. To our knowledge, our study is the first to evaluate SII in predicting PoAF in patients after CABG and revealed that SII was independently associated with PoAF in patients undergoing isolated CABG. Remarkably, SII was also observed to have a higher AUC value for PoAF compared to the AUC value of either NLR or PLR.

Our study results are considered valuable in daily clinical practice. As a simple and readily available prognostic biomarker, SII can be easily obtained from routine complete blood tests without additional costs. Preoperative SII level is believed to be used in assisting the clinicians in identifying high-risk patients and making better medical decisions in clinical practice.

\section{Study Limitations}

This study has some major limitations. First, this study had a retrospective design. Second, the study included a limited number of cases despite the adequate sample size in the power analysis. Third, multivariable analysis was conducted to determine independent predictors; however, some unmeasured confounders might be present, which might affect the study results. Fourth, spot laboratory data was used to determine the relationship between PoAF and SII. Unfortunately, data regarding the post-op SII was not collected. Fifth, data regarding the in-hospital mortality and the choice of arrhythmic medications were not collected. Finally, more prospective studies are warranted to validate the link between PoAF and SII.

\section{CONCLUSIONS}

The present study shows that preoperative SII can be used in predicting PoAF in patients undergoing an isolated CABG.

\section{Ethics}

Ethics Committee Approval: The University of Health Sciences Turkey, Hamidiye Scientific Research Ethics Committee has reviewed and approved our study protocol (decision number: 13/7, date: 09.04.2021).

Informed Consent: Retrospective study. 
Peer-review: Externally and internally peer-reviewed.

\section{Author Contributions}

Concept: M.S., T.C., F.S., S.D., I.S., A.L.O., Design: M.S., T.C., F.S., S.D., I.S., A.L.O., Data Collection and/or Processing: M.S., T.C., F.S., S.D., I.S., A.L.O., Analysis and/or Interpretation: M.S., T.C., F.S., Critical Revision: M.S., T.C., F.S., S.D., A.L.O., Writing: M.S., T.C., F.S., I.S.

Conflict of Interest: The authors have no conflict of interest to declare.

Financial Disclosure: The authors declared that this study has received no financial support.

\section{REFERENCES}

1. Filardo G, Damiano RJ Jr, Ailawadi G, et al. Epidemiology of new-onset atrial fibrillation following coronary artery bypass graft surgery. Heart. 2018;104:985-92.

2. Peretto G, Durante A, Limite LR, Cianflone D. Postoperative arrhythmias after cardiac surgery: incidence, risk factors, and therapeutic management. Cardiol Res Pract. 2014;2014:615987.

3. Lowres N, Mulcahy G, Jin K, Gallagher R, Neubeck L, Freedman B. Incidence of postoperative atrial fibrillation recurrence in patients discharged in sinus rhythm after cardiac surgery: a systematic review and meta-analysis. Interact Cardiovasc Thorac Surg. 2018;26:504-11.

4. Eikelboom R, Sanjanwala R, Le M, Yamashita MH, Arora RC. Postoperative atrial fibrillation after cardiac surgery: a systematic review and meta-analysis. Ann Thorac Surg. 2021;111:544-54.

5. Maesen B, Nijs J, Maessen J, Allessie M, Schotten U. Post-operative atrial fibrillation: a maze of mechanisms. Europace. 2012;14:159-74.

6. Hu YF, Chen YJ, Lin YJ, Chen SA. Inflammation and the pathogenesis of atrial fibrillation. Nat Rev Cardiol. 2015;12:230-43.

7. Jacob KA, Nathoe HM, Dieleman JM, van Osch D, Kluin J, van Dijk D. Inflammation in new-onset atrial fibrillation after cardiac surgery: a systematic review. Eur J Clin Invest. 2014;44:402-28.

8. Gibson PH, Cuthbertson BH, Croal BL, et al. Usefulness of neutrophil/ lymphocyte ratio as predictor of new-onset atrial fibrillation after coronary artery bypass grafting. Am J Cardiol. 2010;105:186-91.
9. Yang R, Chang Q, Meng X, Gao N, Wang W. Prognostic value of Systemic immune-inflammation index in cancer: a meta-analysis. J Cancer. 2018;9:3295-302.

10. Zhong JH, Huang DH, Chen ZY. Prognostic role of systemic immuneinflammation index in solid tumors: a systematic review and metaanalysis. Oncotarget. 2017;8:75381-8.

11. Candemir M, Kiziltunç E, Nurkoç S, Şahinarslan A. Relationship between Systemic Immune-Inflammation Index (SII) and the severity of stable coronary artery disease. Angiology. 2021;72:575-81.

12. Huang J, Zhang Q, Wang R, et al. Systemic immune-inflammatory index predicts clinical outcomes for elderly patients with acute myocardial infarction receiving percutaneous coronary intervention. Med Sci Monit. 2019;25:9690-701.

13. Omae T, Kanmura Y. Management of postoperative atrial fibrillation. J Anesth. 2012;26:429-37.

14. Almassi GH, Schowalter T, Nicolosi AC, et al. Atrial fibrillation after cardiac surgery: a major morbid event? Ann Surg. 1997;226:501-11.

15. Karabacak K, Kubat E, Akyol FB, et al. The C-reactive protein/albumin ratio as a new predictor for postoperative atrial fibrillation after coronary artery bypass graft surgery. J Card Surg. 2020;35:2747-53.

16. Jacob KA, Buijsrogge MP, Frencken JF, et al. White blood cell count and new-onset atrial fibrillation after cardiac surgery. Int J Cardiol. 2017;228:971-6.

17. Geçmen Ç, Babür Güler G, Erdoğan E, et al. SYNTAX score predicts postoperative atrial fibrillation in patients undergoing on-pump isolated coronary artery bypass grafting surgery. Anatol J Cardiol. 2016;16:655-61.

18. Hu B, Yang XR, Xu Y, et al. Systemic immune-inflammation index predicts prognosis of patients after curative resection for hepatocellular carcinoma. Clin Cancer Res. 2014;20:6212-22.

19. Seo M, Yamada T, Morita T, et al. Prognostic value of systemic immuneinflammation index in patients with chronic heart failure. Eur Heart J. 2018;39 (suppl 1):P589. doi: 10.1093/eurheartj/ehy564.P589.

20. Erdoğan M, Erdöl MA, Öztürk S, Durmaz T. Systemic immuneinflammation index is a novel marker to predict functionally significant coronary artery stenosis. Biomark Med. 2020;14:1553-61.

21. Yang YL, Wu CH, Hsu PF, et al. Systemic immune-inflammation index (SII) predicted clinical outcome in patievnts with coronary artery disease. Eur J Clin Invest. 2020;50:el3230. doi: 10.1111/eci.13230. 